\title{
Treatment of respiratory failure: introduction
}

\author{
M. Decramer*, C. Roussos $\#$
}

The present supplement of the European Respiratory Journal contains a number of reviews concerning Treatment of Respiratory Failure. Important progress has been made in this area since the early 1990s. This supplement is the result of a symposium held in Barcelona on January 18, 2003. The symposium was organised by the European Institute of Healthcare, set up by AstraZeneca. It was the fifth symposium of its kind. The goals of the Institute have been discussed extensively in previous supplements [1-4].

As previously, the programme of the present symposium was put together by an independent programme committee. The core of this committee was the two editors of the present supplement. Other members were: K.F. Chung (London, UK), R. Dekhuijzen (Nijmegen, the Netherlands), J. Marini (Minneapolis, MN, USA), R. Rodriguez-Roisin (Barcelona, Spain), and W. MacNee (Edinburgh, UK). The cornerstones of the commitment of AstraZeneca to these symposia are essentially four-fold: 1) the symposia are not product-related; 2) the company has no influence on the scientific programme; 3) scientific excellence is the goal; and 4) the symposia consist of a mixture of basic science and clinical medicine. They are directed primarily at chest physicians who have experience in education and are able to disseminate the information distributed at the symposia in their respective countries. They carry the interest of the previous and present chief editors of the European Respiratory Journal because of the clear commitment to scientific excellence and independence.

Treatment of respiratory failure is an area in which considerable progress has been made since the early 1990s. The pathophysiology of respiratory failure has been the subject of active research leading to better insight into the mechanisms of lung and pump failure [5]. Although new research has furthered insight into possible pathways relating to the development of ventilatory failure, it has not yet been possible to use the data for therapeutic intervention. Mechanical ventilation has been essential to treating patients with ventilatory pump or gas exchange failure. However, the risks and side-effects of mechanical ventilation are now well established. Beside the risk of pulmonary infection, it causes injury to both the lung and the respiratory muscles [6]. The effects of mechanical ventilation on the respiratory muscles are likely to play a significant role in weaning failure. The development of noninvasive ventilation has allowed ventilation with a considerably lower risk of complications [7]. This has permitted the widespread use of ventilation in the treatment of exacerbations of chronic respiratory failure.

Several treatment options are now available for patients with chronic respiratory failure and end-stage lung disease.

\footnotetext{
*Respiratory Division, University Hospital, Katholieke Universiteit Leuven, Leuven, Belgium. " Dept of Critical Care and Pulmonary Services, University of Athens Medical School, Evangelismos Hospital, Athens, Greece.

Correspondence: M. Decramer, Respiratory Division, University Hospital, Herestraat 49, B-3000 Leuven, Belgium. Fax: 3216346803. E-mail: Marc.Decramer@uz.kuleuven.ac.be
}

Beside pharmacological treatment of their lung disease, which remains the first step in treatment, several other treatment options have become available. Home ventilation is now a reasonable option [8]. Rehabilitation produces clear improvements in exercise capacity and health status [9]. Lung volume reduction surgery offers at least palliation in patients to whom little else can be offered. The results of lung transplantation have improved considerably since the early 1990s [10].

The present supplement deals with all of these developments. First, Roussos and Koutsoukou [11] discuss the mechanisms leading to pump and lung failure. The first part of the supplement then deals with acute respiratory failure. GATTINONI et al. [12] discuss new insights into the pathophysiology of acute respiratory distress syndrome and ventilatorinduced lung injury and CALVERLEY [13] discusses the pathophysiology and treatment of chronic obstructive pulmonary disease exacerbations. BROCHARD [14] describes important developments in noninvasive mechanical ventilation.

The second part deals with chronic respiratory failure. SIMONDS [15] gives an overview of home ventilation. DECRAMER [16] discusses rehabilitation and lung volume reduction surgery as treatment modalities. Finally, LAU and PATTERSON [17] share their extensive experience with lung transplantation.

\section{References}

1. Decramer M, Roussos C, Rodriguez-Roisin R. Cytokines and obstructive lung disease: introduction. Eur Respir $J$ 2001; 18: Suppl. 34, 1s-2s.

2. Decramer M, Roussos C. Imaging in lung disease. Eur Respir $J$ 2002; 19: Suppl. 35, 1s-2s.

3. Decramer M, Roussos C, Loddenkemper R. Respiratory infections and tuberculosis. Eur Respir J 2002; 20: Suppl. 36, 1s-2s.

4. Decramer M, Roussos C. Early detection: introduction. Eur Respir J 2003; 21: Suppl. 39, 1s-2s.

5. Roussos C, Macklem PT. The respiratory muscles. $N$ Engl J Med 1982; 307: 786-797.

6. Dos Santos CC, Slutsky AS. Invited review: mechanisms of ventilator-induced lung injury: a perspective. J Appl Physiol 2000; 89: 1645-1655.

7. Brochard L, Mancebo J, Wysocki M, et al. Noninvasive ventilation for acute exacerbations of chronic obstructive pulmonary disease. N Engl J Med 1995; 33: 817-822.

8. Lloyd-Owen SJ, Wedzicha JA. Home ventilation in 16 European countries - a major survey of custom and practice. Eur Respir J 2002; 20: 626S.

9. Lacasse Y, Brosseau L, Milne S, et al. Pulmonary rehabilitation for chronic obstructive pulmonary disease. Cochrane Database Syst Rev: 2002: CD003793.

10. Meyers BF, Lynch J, Truloch EP, Guthrie TJ, Cooper JD, Patterson GA. Lung transplantation: a decade of experience. Ann Surg 1999; 230: 362-370.

11. Roussos C, Koutsoukou A. Respiratory failure. Eur Respir $J$ 2003; 22: Suppl. 47, 3s-14s.

12. Gattinoni L, Carlesso E, Cadringher $\mathrm{P}$, Valenza $\mathrm{F}$, 
Vagginelli F, Chiumello D. Physical and biological triggers of ventilator-induced lung injury and its prevention. Eur Respir J 2003; 22: Suppl. 47, 15s-25s.

13. Calverley PMA. Respiratory failure in chronic obstructive pulmonary disease. Eur Respir J 2003; 22: Suppl. 47, 26s-30s.

14. Brochard L. Mechanical ventilation: invasive versus noninvasive. Eur Respir J 2003; 22: Suppl. 47, 31s-37s.
15. Simonds AK. Home ventilation. Eur Respir $J$ 2003; 22: Suppl. 47, 38s-46s.

16. Decramer M. Treatment of chronic respiratory failure: lung volume reduction surgery versus rehabilitation. Eur Respir $J$ 2003; 22: Suppl. 47, 47s-56s.

17. Lau CL, Patterson GA. Current status of lung transplantation. Eur Respir J 2003; 22: Suppl. 47, 57s-64s. 